\title{
Preface
}

\section{THE HOOVER DAM}

Several years ago, I drove from Las Vegas to the Hoover Dam. The 30-odd-mile trip, which takes some 45 minutes, snakes down Nevada Route 93, the Great Basin Highway, in a southeasterly direction, past the town of Henderson. Departing Las Vegas, which sits at an elevation of approximately 2,000 feet (610 meters), one drives along the spine of the edge of the Basin and Range province, towards a 400-foot (122 meters) elevation at the Hoover Dam. Remember, the dam is at river level.

Once I had parked the car in the Boulder Dam Bridge parking lot, I walked across what, today, is the Mike O'Callaghan-Pat Tillman Memorial Bridge Plaza (Figure 0.1) and saw the four towers that rise out of the water like apparitions (Figure 0.2). These towers measure 338 feet (103 meters) high, and are the dam's water intake towers. They stand, upright, like soldiers in formation, in the waters of Lake Mead, the dam's reservoir, which is situated behind the Hoover Dam (Figure 0.2).

I stood on the dam's rim, with the other tourists that gathered that day, and then peered down this concrete marvel's 726 -feet (221 meters) height, 67 stories down into the abyss of the diverted Colorado River (Figure 0.1). According to our tour guide, the dam has two pipes, which are like tunnels, and each of which can easily envelop a two-lane highway. Hoover Dam's hydroelectric system, we were also told, powers 17 generators that are capable of producing up to 4 billion kilowatts of electricity per annum, making it one of the United States' principal hydroelectric power resources. Indeed, the dam generates electricity for not only Las Vegas and Phoenix, but also Los Angeles. ${ }^{1}$ The dam's operations are self-supporting, via revenues generated by the sale of its electricity.

1 "Hoover Dam generates, on average, about 4 billion kilowatt-hours of hydroelectric power each year for use in Nevada, Arizona, and California - enough to serve 1.3 million people. From 1939 to 1949 , Hoover Powerplant was the world's largest hydroelectric installation; today, it is still one of the country's largest ... There 17 main turbines in the Hoover Powerplant - nine on the Arizona wing and eight on the Nevada wing. The original turbines were replaced through an uprating program between 1986 


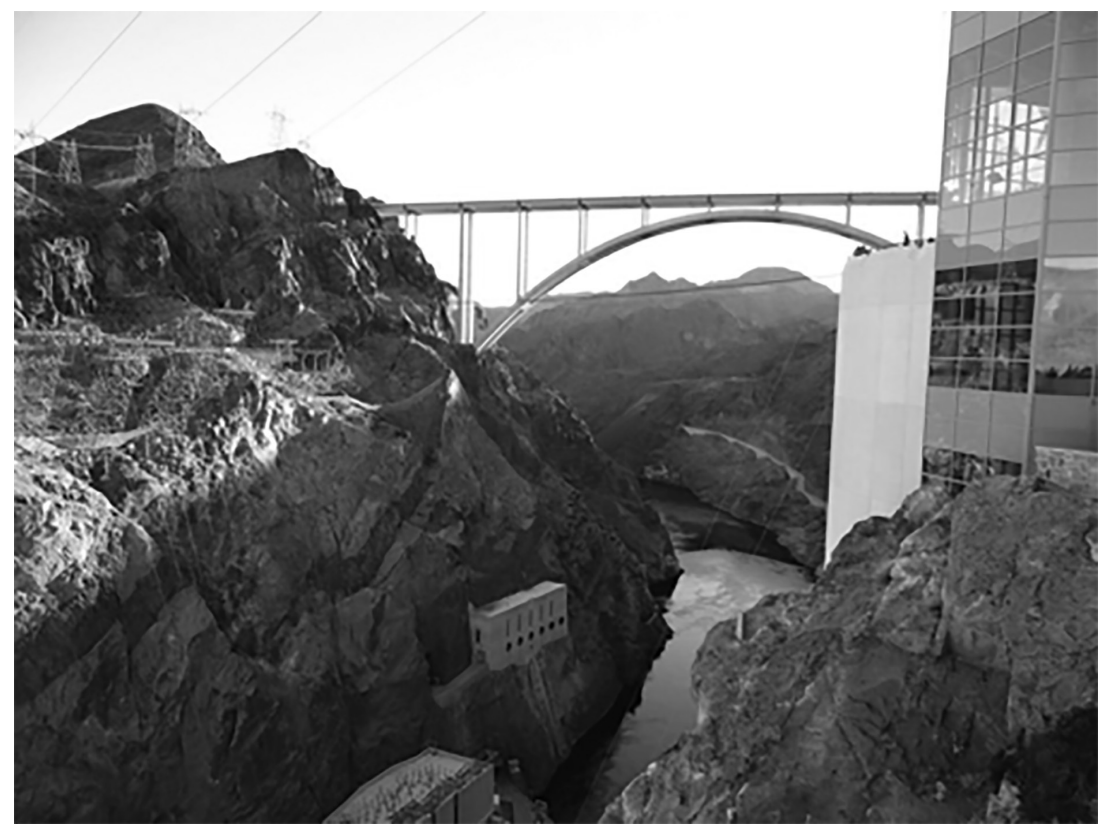

Source: United States Geological Survey (USGS), Mike O'Callaghan-Pat Tillman Memorial Bridge (Credit: Alex Demas, USGS. Public domain), (December 22, 2014) https://www.usgs .gov/media/images/mike-ocallaghan-pat-tillman-memorial-bridge.

\section{Figure 0.1 Hoover Dam's Mike O'Callaghan-Pat Tillman Memorial} Bridge

Hoover Dam was built in the Black Canyon of the Colorado River during the depression era of the twentieth century. The dam's construction was authorized by the Boulder Canyon Project Act of $1928 .^{2}$ Situated along the border between the United States' southwestern states of Nevada and Arizona, its construction began in 1931, during President Herbert Hoover's tenure, and was completed in 1936 during President Franklin D. Roosevelt's first term. It

and 1993." (United States, Department of the Interior, Bureau of Reclamation, Hoover Dam, Frequently Asked Questions and Answers, Hydropower at Hoover Dam (last updated August 1, 2018), https://www.usbr.gov/lc/hooverdam/faqs/powerfaq.html.)

2 Act of December 21, 1928, c. 42,45 Stat. 1057, codified at 43 U.S.C. $\S \S 617$ et seq. On the Boulder Canyon Project Act of 1928, see Itzchak E. Kornfeld, Transboundary Water Disputes: State Conflict and the Assessment of their Adjudication (2019) at 197-210. 


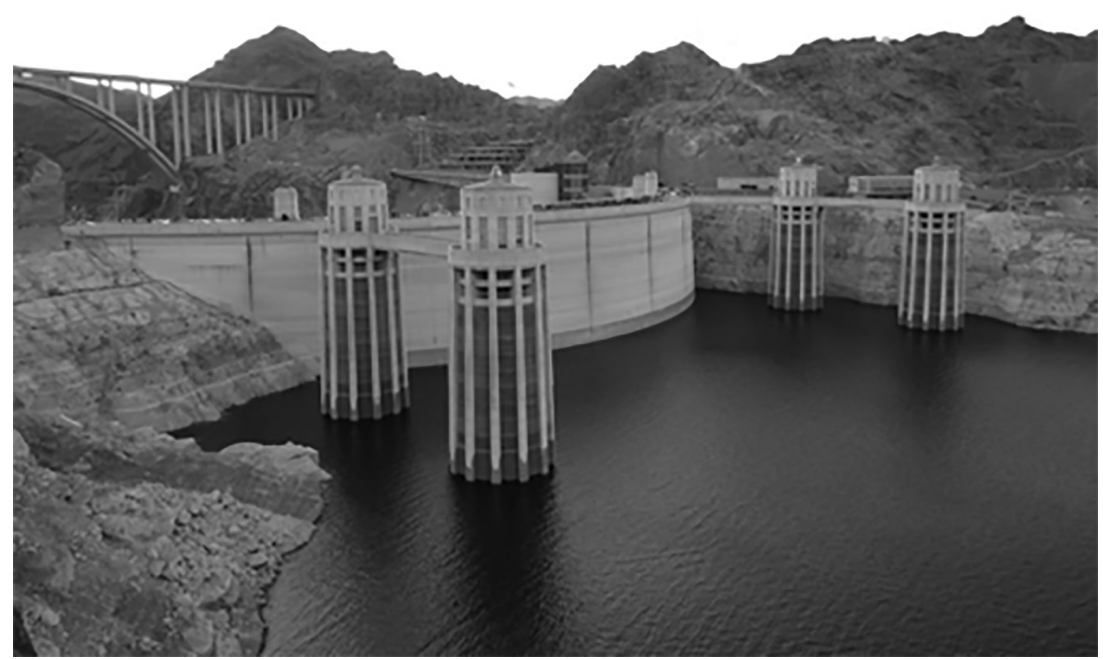

Source: United States Geological Survey (USGS), Hoover Dam Intake Towers (Credit: Alex Demas, USGS. Public domain), (December 22, 2014), https://www.usgs.gov/media/images/ hoover-dam-intake-towers.

\section{Figure 0.2 Hoover Dam's water intake towers}

was the first mega-dam ${ }^{3}$ ever built. Interestingly, the United States Department of the Interior's Bureau of Reclamation still declares that "Hoover Dam was the first of the large reclamation projects along the Colorado River." ${ }^{4}$ Reclaim or reclamation are defined as "to bring (waste land or land formerly under water) under cultivation." 5

3 "Although there is no universal definition of what qualifies as a mega dam, as a general rule they are large structures over 15 metres in height generating over 400 megawatts of power on average." Emanuele Bompan, Marirosa Iannelli, Riccardo Pravettoni, and Federica Fragapane, Water and Power: Mega-Dams, Mega-Damage? SciDevNet (March 22, 2017), https://www.scidev.net/global/water/data-visualisation/ water-power-mega-dams-mega-damage.html.

4 United States Department of the Interior's Bureau of Reclamation, Hoover Dam: Learning Packet (1999), at 18 https://www.usbr.gov/lc/hooverdam/educate/hoovered .pdf.

5 See definition of Reclaim at https://www.google.com/search?q=definition + of + reclaim\&oq $=$ definition + of + reclaim\&aqs $=$ chrome $.69 i 57 j 69 i 60.30996 j 0 j 4$ $\&$ sourceid $=$ chrome $\&$ ie $=\mathrm{UTF}-8$. 
Native peoples (also known as American Indians) have lived in the Las Vegas region for over 10,000 years. Indeed, scientists have found pictographs, petroglyphs, and baskets, as well as other corroborating evidence, in various sites, including the Gypsum Cave, a five-room cavern about 12 miles east of Las Vegas. ${ }^{6}$ Artifacts linked to early human habitation were discovered in the cave, evidencing the area's ecosystem and the types of lives that these people lived. ${ }^{7}$ Numerous native tribes, including, the Hopi, Mojave, and Paiute, have lived in the region for over a millennium. They taught themselves how to both survive and to live in the desert and along the Colorado River. Some of the treasures that existed pre-inundation, and probably a number of Indian burial mounds, lie beneath the dam and its reservoir, Lake Mead.

But for the Hoover Dam, America's World War II efforts would have been devoid of the "electrical power it was providing to southern California, home of some of the nation's largest defense plants, where planes and tanks and other armaments would be built on a round-the-clock basis once America's mighty industrial machine went to war." Moreover, Hoover Dam's construction came during the Great Depression, a time of pervasive destitution and widespread unemployment. ${ }^{9}$ This colossal endeavor "not only provided jobs to thousands of unemployed men but offered some of the most complex engineering challenges ever tackled. Perhaps as important, it asserted America's ability to overcome extreme adversity with technical ingenuity, physical prowess, and unwavering resolve." ${ }^{10}$ Indeed,

[t]he project's goal: Build a huge dam - the largest ever built - across the Colorado River on the Nevada-Arizona border to harness the power and riches of the mighty river. Completed in 1936, Hoover Dam, ... through the generation of electricity and the orderly dispersal of its waters, fueled the incredible growth of southern

6 Amy Gilreath, Gypsum Cave, O·n·e nevada encyclopedia (January 4, 2011), http://www.onlinenevada.org/articles/gypsum-cave.

$7 \mathrm{Ibid}$. Dates of wooden dart fragments in the cave have yielded radiocarbon dates between 3,300 and 4,250 years before present (BP). However, the oldest item found, a woven basket, has been dated at 9,280 years BP.

8 Christine Pfaff, Safeguarding Hoover Dam during World War II, 35 Prologue Mag. No. 2 (Summer 2003), https://www.archives.gov/publications/prologue/2003/ summer/hoover-dam-1.html.

9 "At the height of the Depression in 1933, 24.9\% of the total work force or $12,830,000$ [i.e., 3,207,500 individuals] people [were] unemployed. Although farmers technically were not counted among the unemployed, drastic drops in farm commodity prices resulted in farmers losing their lands and homes to foreclosure." Franklin D. Roosevelt Presidential Library and Museum, Great Depression Facts (2016), https:// www.fdrlibrary.org/great-depression-facts.

10 Pfaff, see note 8. 
California - its large cities, its industrial base, its massive agricultural industry - and created Lake Mead, the world's largest man-made reservoir. ${ }^{11}$

Without question, given the advent of World War II, the country's demand for electricity, primarily western hydro-generated power, skyrocketed. ${ }^{12}$ Moreover, at the outbreak of the war, the three Axis Nations (Germany, Italy, and Japan) possessed much more available electric power than the United States. ${ }^{13}$ In 1942 the Department of the Interior initiated a "war program" in which it recognized that its generation of power for the war would demand a "war budget of $\$ 56$ billion [which] will require 154 billion kilowatt hours (kWh) of electric energy annually for the manufacture of airplanes, tanks, guns, warships, and fighting material, and to equip and serve the men of the Army, Navy, and Marine Corps." 14

Furthermore, for every dollar expended for use by the wartime industrial complex, approximately, $2.75 \mathrm{kWh}$ hours of electric power were required. ${ }^{15}$ That demand outstripped the overall production capacity of the entirety of the then-existing electric utilities in the United States. "In "In 1942, 8.5 billion $\mathrm{kWh}$ of electric power was required to produce enough aluminum to meet the President's goal of 60,000 new planes."17

\section{THE BONNEVILLE LOCK \& DAM}

My next trip was to the Bonneville Lock \& Dam, which is located some 40 miles from downtown Portland, Oregon, in the heart of the Columbia River Gorge. The dam was constructed across three islands - Robins, Bradford, and Cascade - in the Columbia River, at Columbia River Mile (RM) 146. Once known as the Cascade Rapids, that section of the river was a major obstacle to navigation. ${ }^{18}$ Built by the United States Army Corps of Engineers for both navi-

\section{Ibid.}

12 United States Department of the Interior, Bureau of Reclamation, Reclamation, Lower Colorado Region, A Century of Cooperation, Reclamation and Arizona, World War II - Reclamation, Arizona, and Hoover Dam (2003), at Hoover Dam's Importance to the War Effort. https://www.usbr.gov/lc/phoenix/AZ100/1940/topstory.html.

13 Ibid.

14 Ibid.

15 Course Hero, A 4500 kw Powerplant Was Constructed in 1909 Five (2019), https://www.coursehero.com/file/p1n88bv/A-4500-kW-powerplant-was-constructed -and-in-1909-five-generators-were-in.

16 Ibid.

17 Ibid.

18 Lyn Topinka, The Columbia River: A Photographic Journey, Lewis \& Clark's Columbia River - "200 Years Later," Bonneville Dam and Bonneville Locks (2019), $\mathrm{http}: / /$ columbiariverimages.com/Regions/Places/bonneville_dam.html. 


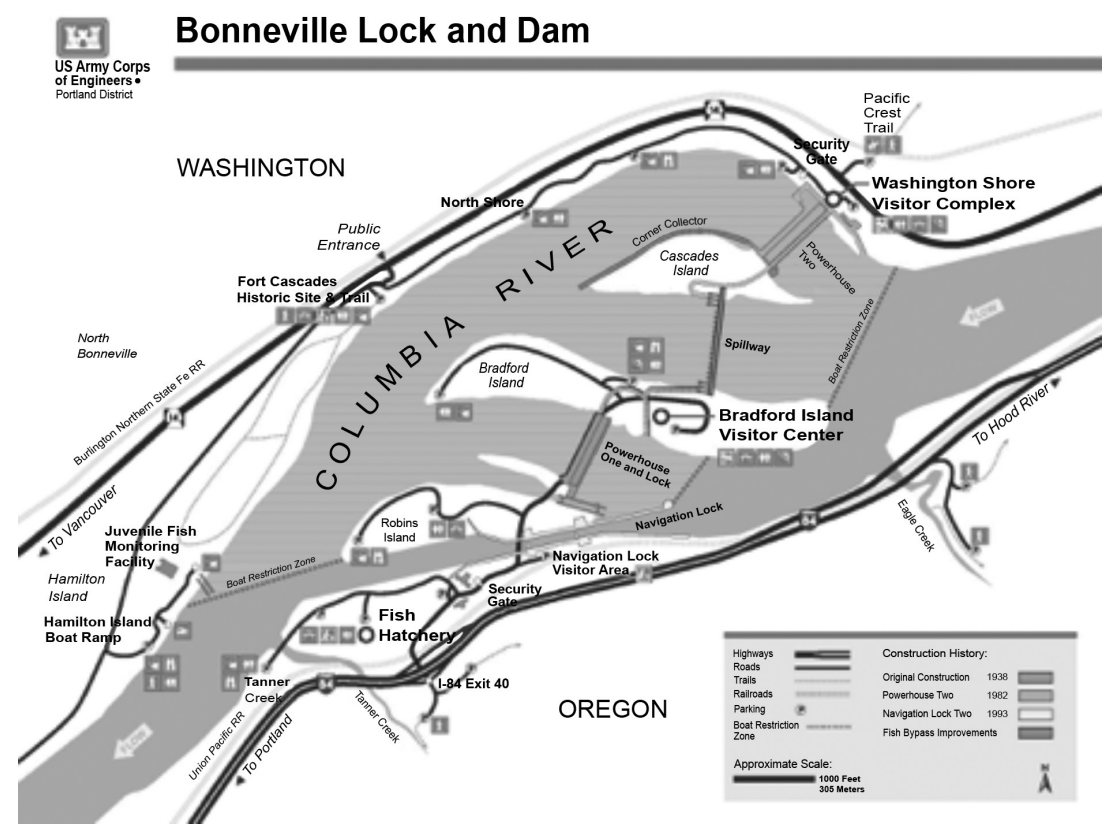

Source: United States Army Corps of Engineers (ACE), Portland District, Bonneville Lock \& Dam (u.d.), https://www.nwp.usace.army.mil/bonneville.

\section{Figure 0.3 Schematic of the Bonneville Lock and Dam}

gation along the Columbia River, and for the generation of electricity, its first powerhouse, spillway, and original navigation locks were built and completed in $1938^{19}$ (Figure 0.3). The lock and dam have since inception been operated by the Corps. It was the first federal lock and dam on the Columbia and Snake rivers. ${ }^{20}$ The dam was constructed to improve navigation on Columbia River and to deliver hydropower to the Pacific Northwest, also known as Cascadia, which includes the states of Idaho, Oregon, and Washington (Figure 0.4). Bonneville was part of President Franklin D. Roosevelt's New Deal, Public Works Administration development undertaking. It was a major government undertaking during the mid to late 1930s and contributed a partial solution to the growing employment needs during the Great Depression. ${ }^{21}$

$\begin{array}{ll}{ }_{20}^{19} & \text { Ibid. } \\ 21 & \text { Ibid. } \\ 21 & \text { Ibid. }\end{array}$




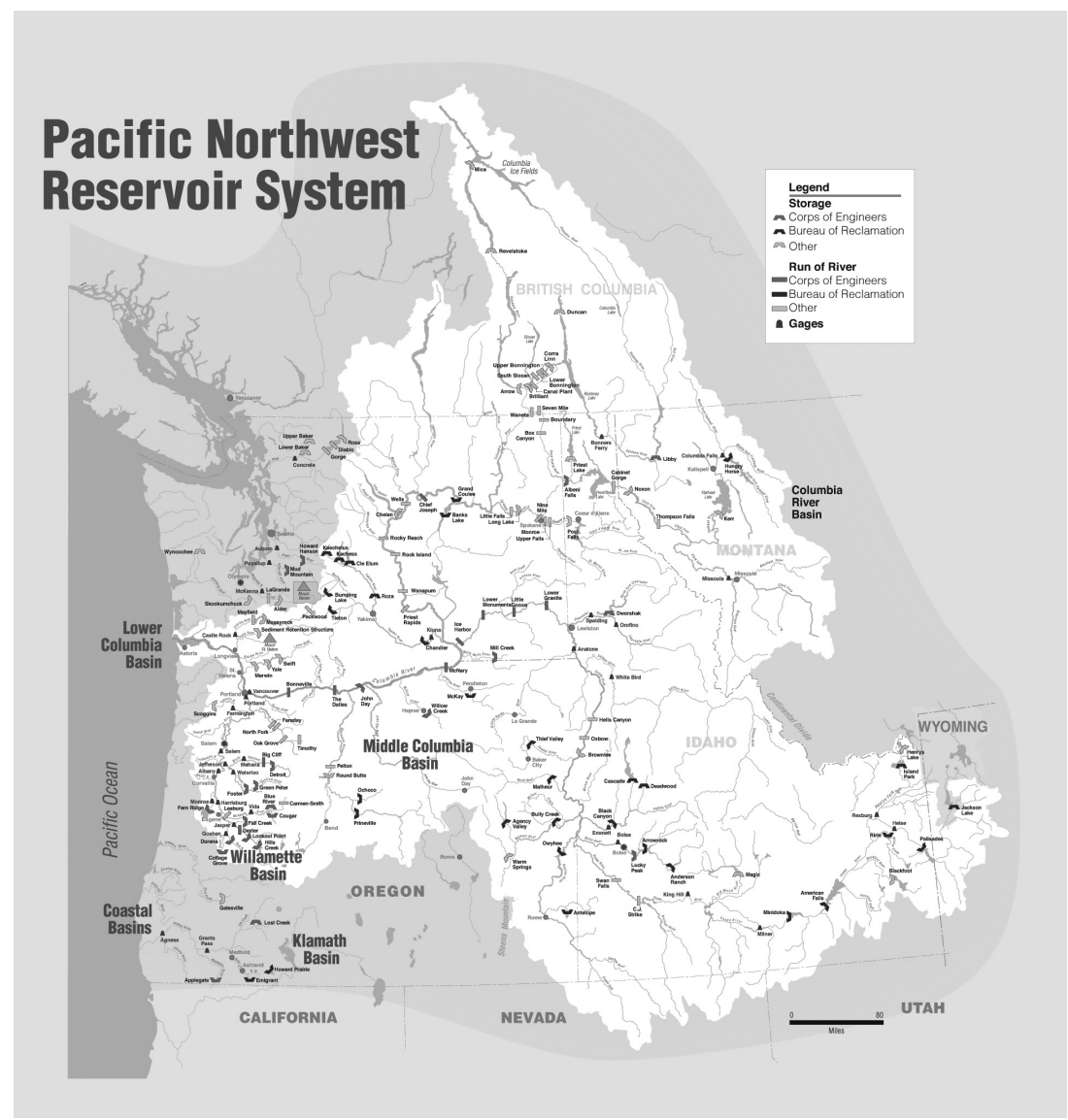

Source: United States Army Corps of Engineers - Portland District Visual Information, Pacific Northwest River System (January 11, 2010), https://commons.wikimedia.org/wiki/File: Pacific_Northwest_River_System.png.

\section{Figure 0.4 The Columbia River Basin}

When the United States declared war on Japan on December 8, 1941, the war effort's need for enormous quantities of electrical power turned out to be instantly obvious. The Bonneville Dam commenced generating electricity in May 1938 and, like its southern kin, the Hoover Dam, was an extremely timely contributor for this demand. ${ }^{22}$ Power was distributed to both public and private

22 William F. Willingham, Bonneville Dam's Contribution to the War Effort, in Builders and Fighters: U.S. Army Engineers in World War II, Barry W. Fowle, General 
customers across the Pacific Northwest from the Bonneville Dam's power plant, by the Bonneville Power Administration (BPA) ${ }^{23}$ Indeed, throughout World War II, the BPA provided power to shipyards at Portland, Oregon, and on the Puget Sound in Washington, including the Puget Sound Naval Shipyard, a massive military industrial complex located in Bremerton, Washington, to aluminum plants scattered throughout the region, and to airplane factories near Seattle. ${ }^{24}$

\section{A NEW MODEL FOR DAM DEVELOPMENT}

However, the blessings that the Bonneville and two of its sister dams on the Columbia River - the Grand Coulee and the Rock Island - gave to the Roosevelt Administration, the war effort, and to white Americans, turned into a curse for the native peoples - for example the Cascade band of the Yakama Nation - who had lived along the banks of the Columbia for millennia. ${ }^{25}$ The dam planners literally eradicated the Yakima flourishing villages in order to clear a pathway for the three dams. Although the destroyed settlements were subsequently replaced, these were and continue to be 31 dilapidated encampments. ${ }^{26}$ Like their predecessors, these pseudo-villages are active fishing villages. However, even today,

[d]eplorable conditions can be found at nearly all of them. The sites that are considered the best for fishing are overcrowded, unsanitary and unsafe ... Electricity is scarce at all of the fishing sites, prompting residents to patch together webs of extension cords that crisscross gravel paths connected to slapdash housing made out of plywood and tarps. Often, those cords lie in puddles after a rain or near propane tanks - a spark away from trouble. Poverty plagues the communities, making even

Editor, U.S. Army Corps of Engineers (1992), 295-300, reproduced in National Defense University, Industrial College of the Armed Forces, The Big "L": American Logistics in World War II, Alan Gropman ed. (1997), at 199-200.

23 Ibid.

24 Louise M. Reh, Fifty Dollars an Acre, A History of the Puget Sound Naval Shipyard. 1891 to 1916 (1983).

${ }_{25}$ Molly Harbarger, Decrepit Fish Camps Built on Broken Promises: Four Tribes that Had Fishing Villages Wiped Out in the Last Century Are Left Waiting for the Federal Government to Provide Better Housing, The Oregonian, March 11, 2016, https://www.oregonlive.com/pacific-northwest-news/page/tribal_housing_a_run_of broken.html.

${ }_{26}$ Ibid. 
small fixes like insulating their homes seem out of reach. Children and elderly tribal members are surrounded by broken glass and rusted edges.

When the dams were being built, federal officials promised adequate permanent housing for the Warm Springs, Yakama Nation, Umatilla and Nez Perce tribes that fish for salmon in the Columbia River. That promise has yet to materialize.

Federal officials in the 1970s began to painstakingly relocate several predominantly white towns that were in the path of the dams. But none of the centuries-old Native American settlements received the same treatment. It took the federal government 20 years after the first dam opened to designate even the first temporary fishing spots for tribal use. ${ }^{27}$

The vile and inhumane system or pattern of treating indigenous people, established by the U.S. government in the 1930s, is now the worldwide model, as discussed in the succeeding chapters. But, that treatment was and is not what the predominant or ruling population receives. To reiterate the foregoing injustice: "Federal officials in the 1970 s began to painstakingly relocate several predominantly white towns that were in the path of the dams. But none of the centuries-old Native American settlements received the same treatment. It took the federal government 20 years after the first dam opened to designate even the first temporary fishing spots for tribal use."

In 2013, the U.S. Army Corps of Engineers office in Portland publicly acknowledged it never fulfilled its duty to find permanent housing for tribal fishing families displaced first by the construction of Bonneville Dam 80 years earlier and then The Dalles and John Day dams about 20 years after. No infrastructure has been put in place for year-round living, and only a handful of permanent houses have been built to help compensate for a lost way of life for what is likely thousands of tribal members. ${ }^{28}$

So much for American democracy, constitutionalism, exceptionalism, and its duty to promote and safeguard human rights. Indeed, one thing white residents had that the tribes lacked and continue to need was friends in Congress. They enlisted U.S. Rep. Mike McCormack, who wrote assurances into the Water Development Act of 1974. His amendment paved the way to relocate an entire

$27 \quad$ Ibid.

28 Ibid. (emphasis added). "When it came time to move people living in the path of the dams, here's how the federal government allocated the resources: $\$ 52$ million went to move thousands of residents of seven mostly white towns. And $\$ 210,000$ was spent to move 44 tribal members ... That meant the Army Corps spent about 248 times more on white residents than on tribal members." Ibid. (emphasis added). 
town. ${ }^{29}$ That amendment, observed the Oregonian newspaper, would in due course require the Army Corps of Engineers to

design and build the amenities for a whole new city - streets, a sewage system, electrical connections and water storage to the tune of \$35 million. Today, North Bonneville occupies 2.6-square-miles west of the Bridge of the Gods. A school is centrally located in the Washington city. During a hot summer day in 2015, kids rode bikes through the quiet streets while dads mowed lawns. ${ }^{30}$

America's lead has been followed by every country that has built mega-dams. Indeed, I have witnessed the same poor treatment of indigenous peoples at other hydroelectric dams, in other parts of the world. As a matter of fact, during the 1990s, numerous groups across the globe sought to alter the direction that multi-billion dollar construction and design corporations, along with governments from the developing world, were moving the dam construction enterprise towards while hurting indigenous people who "were in the way" of the dams. They established the World Commission on Dams (WCD).

The WCD was a global multi-participant body established in 1997 by the World Conservation Union (IUCN) and the World Bank in reaction to the mounting opposition to large dam projects during the twentieth century. ${ }^{31}$ The Commission's mandate was to assess the effectiveness of the development of large and mega-dams and to advance internationally suitable standards for the design, construction, and operation of these dams. Consequently, following three years of work and consultations, the Commission issued a comprehensive 404-page report, with appendices, in November of 2000. The report contained an extremely detailed list of guidelines and principles for dam building. The WCD observed that while "dams have made an important and significant contribution to human development, and benefits derived from them have been considerable ... in too many cases an unacceptable and often unnecessary price has been paid to secure those benefits, especially in social and environmental terms, by people displaced, by communities downstream, by taxpayers and by the natural environment." 32

\section{Ibid.}

Ibid.

31 International Rivers, The World Commission on Dams (u.d.), https://www. internationalrivers.org/campaigns/the-world-commission-on-dams.

32 Dams and Development: A New Framework for Decision-Making, The Report of the World Commission on Dams (November 2000) xxviii (emphasis added), https://ia800301.us.archive.org/3/items/DamsAndDevelopmentANewFrame workForDecision-making/wcdreport.pdf. 
Professor Kader Asmal, a South African, ${ }^{33}$ who was appointed the Chair of WCD, stated the following in his Chair's preface, titled Globalisation From Below:

[I]f politics is the art of the possible, this document is a work of art. It redefines what is possible to all of us, for all of us, at a time when water pressure on governments has never been more intense. Consider: on this blue planet, less than $2.5 \%$ of our water is fresh, less than $33 \%$ of fresh water is fluid, less than $1.7 \%$ of fluid water runs in streams. And we have been stopping even these. We dammed half our world's rivers at unprecedented rates of one per hour, and at unprecedented scales of over 45000 dams more than four storeys high.

Rather than attempt to summarize or recapitulate the salient portions of the Commission's report, I quote directly from it as follows:

The global debate about large dams is at once overwhelmingly complex and fundamentally simple. It is complex because the issues are not confined to the design, construction and operation of dams themselves but embrace the range of social, environmental and political choices on which the human aspiration to development and improved well-being depend. Dams fundamentally alter rivers and the use of a natural resource, frequently entailing a reallocation of benefits from local riparian users to new groups of beneficiaries at a regional or national level. At the heart of the dams debate are issues of equity, governance, justice and power - issues that underlie the many intractable problems faced by humanity. The dams debate is simple because behind the array of facts and figures, of economic statistics and engineering calculations, lie a number of basic and easily understood principles. If adhered to and routinely applied, these principles would not only go a long way towards responding to the controversy surrounding dams, but would markedly improve decision-making on water and energy resources, achieving better outcomes. In identifying these principles, the World Commission on Dams (WCD) has not had to look far; they are the same principles that emerge from the global commitments to human rights, development and sustainability ... The evidence we present is compelling ...

$[T]$ here can no longer be any justifiable doubt about the following:

- Dams have made an important and significant contribution to human development, and the benefits derived from them have been considerable.

33 Abdul Kader Asmal (8 October 1934-22 June 2011) was born in the rural town of Stanger, KwaZulu Natal (then Natal). The son of South African-born-Indian parentage. A lawyer, he specialized in human rights, labor and international law, and was Dean of the Faculty of Arts at the University of Dublin (1980-1986). In the April 1994 general election, Asmal was 22nd in the ranking for the ANC's National Assembly, and became a Member of Parliament. He was appointed Minister of Water Affairs and Forestry in May 1994, a position he held until 1999, and held other ministerial positions in the South African government. SAHO, South African History Online, Professor Abdul Kader Asmal (2019), https://www.sahistory.org.za/people/professor -kader-abdul-asmal. 
- In too many cases an unacceptable and often unnecessary price has been paid to secure those benefits, especially in social and environmental terms, by people displaced, by communities downstream, by taxpayers and by the natural environment.

- Lack of equity in the distribution of benefits has called into question the value of many dams in meeting water and energy development needs when compared with the alternatives.

- By bringing to the table all those whose rights are involved and who bear the risks associated with different options for water and energy resources development, the conditions for a positive resolution of competing interests and conflicts are created.

- Negotiating outcomes will greatly improve the development effectiveness of water and energy projects by eliminating unfavourable projects at an early stage, and by offering as a choice only those options that key stakeholders agree represent the best ones to meet the needs in question. The direction we must take is clear. It is to break through the traditional boundaries of thinking and look at these issues from a different perspective. Our recommendations develop a rationale and framework that responds to this critical need and offers scope for progress that no single perspective can offer on its own. It will ensure that decision-making on water and energy development:

- reflects a comprehensive approach to integrating social, environmental and economic dimensions of development;

- creates greater levels of transparency and certainty for all involved; and

- increases levels of confidence in the ability of nations and communities to meet their future water and energy needs. There are no shortcuts to equitable and sustainable development. The evidence of success and failure ... present[ed] provides the best rationale why the "business as usual" scenario is neither a feasible nor a desirable option. ${ }^{34}$

The human rights perspective and fiasco presented in the succeeding chapters demonstrates both the folly and tragedy of constructing mega-dams utilizing the traditional boundaries of thinking and viewpoints.

This volume presents seven case studies of mega-dams and their severe consequences for the indigenous peoples that stood or stand in the way of building dams in locations selected by far away politicians, bureaucrats, and engineers. This triumvirate presents itself as a well-meaning deity. However, it routinely fails to consult the local peoples; the very people who have for millennia lived and earned a meager living, where the proposed dam will be located.

Whether the dam is located in Canada, India, Laos, Paraguay, Senegal, or Tanzania, the story, as I see it, is always precisely the same: a government with a colonialist, and more often than not bigoted or sectarian, mindset decides to situate and build a dam where it feels the structure "should be," regardless of how the locals will be affected. The locals, who almost routinely are members

34 Dams and Development: A New Framework for Decision-Making, at xxvii-xxix. 
of a minority or aboriginal group, are then uprooted or ousted from their homes, their lands, and the area where they and their ancestors grew crops or fished or made pottery from a rich zonal clay, that is simply not present in the area to which they have been relocated. Moreover, in some situations, such as those in Senegal and Egypt, virulent diseases such as schistosomiasis break out due to standing water caused by the dam structure.

These government actions are generally funded and supported by the World Bank and/or other regional development banks, such as the Inter-American Development Bank. Recall that the World Bank was one of the organizations that participated in the WCD. Nevertheless, it has, as many critics have noted, ignored the WCD's guidelines and recommendations. ${ }^{35}$

Finally, as should become clear from reading the succeeding chapters, dams are also a classic example of Garret Hardin's tragedy of the commons. ${ }^{36}$

35 See e.g., Phil Williams and Patrick McCully, Lies, Dam Lies, The Guardian (UK), November 22, 2000, https://www.theguardian.com/society/2000/nov/22/ guardiansocietysupplement4. ("Activists participating in the 'consultation' processes of the bank felt they were ignored or misrepresented. Others had seen progressive policies adopted on paper, then routinely ignored by bank staff ... Dam promoters, guilty of 40 years of ecologic and social destruction, [are] to be held accountable. Reparations for the millions of dispossessed people and restoration of river ecosystems [are] to be advocated."); Robert Goodland, The World Bank Versus the World Commission on Dams, 3 Viewpoint No. 2 (2010), http:/www.water-alternatives.org/index.php/allabs/ 99-a3-2-22/file. ("The World Bank Group (WBG) has long resisted guidelines from reformers and the World Commission on Dams (WCD) requiring large dam projects to internalise the social and environmental costs of dam construction. Despite some progress, the Bank continues to resist calls for it to eschew countries' use of violence in removing residents from areas to be flooded by reservoirs, compensate residents adequately for their losses, or involve affected people in planning for big dams.").

36 Garret Hardin, The Tragedy of the Commons, 162 Science (1968) 1243. 